Bangladesh J. Plant Taxon. 22(1): 47-54, 2015 (June)

(C) 2015 Bangladesh Association of Plant Taxonomists

\title{
A REVISED INFRAGENERIC CLASSIFICATION OF DIMERIA R. BR. (POACEAE: ANDROPOGONEAE)
}

\author{
M.S. Kiran RaJ ${ }^{1}$, M. Sivadasan ${ }^{2,5}$, J.F. Veldkamp ${ }^{3}$, A.H. Alfarhan ${ }^{2}$ \\ AND A.S.M. AMAL TAMIMI ${ }^{4}$ \\ Department of Botany, Sree Narayana College, Cherthala 688 582, Alappuzha, Kerala, India
}

Keywords: Dimeriinae; New subspecies; New synonyms; Panicoideae; Sectional classification; Typification.

\begin{abstract}
The four sections of the little known genus Dimeria R. Br. of the rather anomalous paleotropical subtribe Dimeriinae Hack. (Poaceae-PanicoideaeAndropogoneae) are revised. A key is provided. Three Peninsular Indian species, viz. Dimeria sivarajanii, D. idukkiensis and D. borii are treated here as subspecies of $D$. bialata, $D$. kurumthotticalana and $D$. mooneyi respectively; and five, viz. D. chelariensis, D. copei, D. eradii, D. jayachandranii and D. kollimalayana are reduced to synonymy.
\end{abstract}

\section{Introduction}

Dimeria R. Br. (Poaceae) is a little known genus with about 65 species (Teerawatananon et al., 2014). They are adapted to arid habitats and range from India to China, Korea, Indonesia, Micronesia, and northern Australia and to Sri Lanka and Madagascar (Bor, 1953; Clayton et al., 2006; Kiran Raj and Sivadasan, 2008; Kiran Raj et al., 2013a, b; Kiran Raj et al., 2015) (Fig. 1).

It used to be the only genus of the rather anomalous paleotropical subtribe Dimeriinae Hackel (1889) until Nanooravia Kiran Raj \& Sivad. (Kiran Raj et al., 2013a, b) was described from India. The subtribe is distinguished by espatheate inflorescences consisting of 1-11 digitate racemes with tough raches and strongly laterally flattened solitary spikelets by which it differs from all other Andropogoneae Dumort. (Clayton, 1972). Brown (1810) placed it between Imperata Cirillo and Ischaemum L. Endlicher (1836) included it in the Andropogoneae between Zoysia Willd. and Pleuroplitis Trin. (= Arthraxon P. Beauv.). Steudel (1854) treated six species in Andropogoneae between Euklaston Steud. (= Andropogon L.) and Pterygostachyum Nees ex Steud., Psilostachys Steud. (synonyms of Dimeria) and Amblyachyrum Hochst. ex Steud. (= Apocopis Nees). Bentham (1881) included it in the subtribe Arthraxonae J. Presl together with Apocopis Nees and Arthraxon P. Beauv., but in 1883 in the Andropogoneae s.l. (Bentham, 1883).

Hackel (1889) had 12 species, 2 subspecies, and 10 varieties and regarded it as close to the Sacchareae Dumort., and very much to the Tristegineae Nees. For a discussion on the latter tribe see Veldkamp (2015).

\footnotetext{
${ }^{1}$ Formerly at: Department of Botany, University of Calicut, P.O. Box 673 635, Kerala, India

${ }^{2}$ Department of Botany \& Microbiology, College of Science, King Saud University, P.O. Box 2455, Riyadh 11451, Kingdom of Saudi Arabia

${ }^{3}$ Naturalis Biodiversity Center, P.O. Box 9517, 2300 RA Leiden, The Netherlands

${ }^{4}$ Department of Biology, College of Science, Princess Nora bint Abdulrahman University, P.O. Box 87991, Riyadh 11652, Kingdom of Saudi Arabia

${ }^{5}$ Corresponding author. Email: drmsivadasan@gmail.com
} 
Roberty (1960) found the genus Dimeria so homogeneous, that in his "cohors" Dimeriastreae he accepted only a single species, D. avenacea (Retz.) C.E.C. Fisch., with not less than 22 subvarieties all with invalid names, because he did not follow the Linnean infraspecific classification.

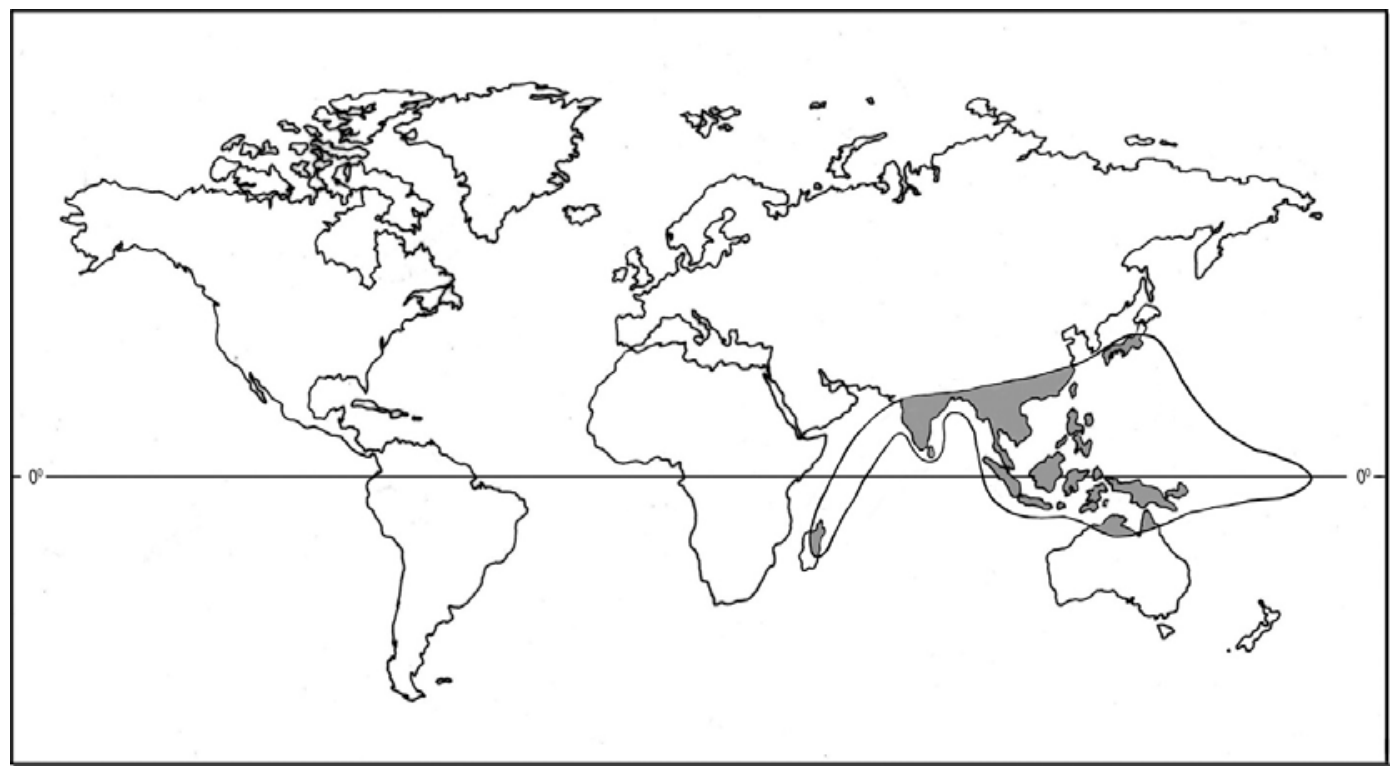

Fig. 1. Distribution of Dimeria R. Br.

Clayton and Renvoize (1986) regarded it as derived from the Ischaeminae J. Presl by suppression of the sessile spikelet. This might as well be loss of the pedicelled ones, as was observed by Miquel (1851: "rudimentary pedicels"), but by no one else. Kellogg and Watson (1993) in their phylogenetic analysis based on morphological data treated Dimeria as a sister group of Cleistachne Benth. of the subtribe Sorghinae Bluff et al. with both genera nesting in a clade. Estep et al. (2014) in a nuclear molecular study found Dimeria nested in a clade within Ischaemum, but with little basal support, so a reduction of Dimeria to Ischaemum seems premature.

The majority of the species (34 out of 65: Table 1) is confined to Peninsular India (Hackel, 1889; Hooker, 1896; Bor, 1953; Kiran Raj, 2008; Kiran Raj et al., 2013a, b) indicating it to be at least a centre of speciation of the subtribe. In Southeast Asia, approximately 14 species have been reported for Indo-China, Malesia and China (Camus and Camus, 1922; Ridley, 1925; Jansen, 1953; Schmid, 1958; Henty, 1969; Gilliland, 1971; Lazarides, 1980; Chen and Phillips, 2006; Teerawatananon et al., 2014).

\section{Sectional classification of Dimeria by Bor (1953)}

The first infrageneric classification of the genus was by Bor (1953), who treated the species for India, Sri Lanka (Ceylon), and Myanmar (Burma) as belonging to three sections viz. Dimeria sect. Annulares Bor, sect. Capillares Bor, and sect. Loriformes Bor and the sections were recognized based on rachis and pedicel characters. As the type species, D. acinaciformis $\mathrm{R}$. Br., is from Australia, he did not mention a section Dimeria in his treatise. 
Table 1. The sections of Dimeria R. Br. and their Peninsular Indian taxa.

\begin{tabular}{|c|c|}
\hline I. Dimeria sect. Dimeria & $\begin{array}{l}\text { Dimeria acutipes Bor } \\
\text { D. agasthyamalayana Kiran Raj \& Ravi } \\
\text { D. aristata (Hack.) Senaratna } \\
\text { D. avenacea (Retz.) C.E.C.Fisch. } \\
\text { D. connivens Hack. } \\
\text { D. copeana Sreek.,V.J.Nair \& N.C. Nair. } \\
\text { (= D. chelariensis Ravi, syn. nov.) } \\
\text { D. fuscescens Trin. } \\
\text { D. kanjirapallilana Jacob } \\
\text { D. lehmannii Hack. (= D. alata Hook. f.) } \\
\text { D. orissae Bor } \\
\text { D. ornithopoda Trin. } \\
\text { D. trimenii Hook. f. }\end{array}$ \\
\hline II. Dimeria sect. Annulares & $\begin{array}{l}\text { D. veldkampii Kiran Raj \& Sivad. } \\
\text { D. woodrowii Stapf }\end{array}$ \\
\hline III. Dimeria sect. Capillares & $\begin{array}{l}\text { D. gracilis Nees ex Steud. (= D. laxiuscula Thw. \& Trimen) } \\
\text { D. hohenackeri Hochst. ex Miq. } \\
\text { D. stapfiana C.E. Hubb. ex Pilg. } \\
\text { D. stapfiana var. blatteri (Bor) M.R. Almeida }\end{array}$ \\
\hline IV. Dimeria sect. Loriformes & $\begin{array}{l}\text { D. balakrishnaniana K. Ravik., Sreek. \& V. Lakshm. } \\
\text { D. bialata C.E.C. Fisch. } \\
\text { D. bialata subsp. sivarajanii (N. Mohanan \& Ravi) Kiran Raj \& Sivad., } \\
\text { comb. \& stat. nov. (=Dimeria sivarajanii N. Mohanan \& Ravi, Rheedea } \\
\text { 6(2): } 47.1996) \\
\text { D. kalavoorensis Ravi (=D. copei Ravi, syn. nov.) } \\
\text { D. deccanensis Bor (=D. kollimalayana M. Mohanan \& A.V.N. Rao, syn. } \\
\text { nov.; =D. jayachandranii Arisdason \& P. Daniel, syn. nov.) } \\
\text { D. fischeri Bor } \\
\text { D. jainii Sreek., V.J. Nair \& N.C. Nair } \\
\text { D. josephii Ravi \& N. Mohanan } \\
\text { D. kurumthotticalana Jacob (=D. ceylanica Bor; =D. sreenarayanae Ravi } \\
\text { \& Anil Kumar) } \\
\text { D. kurumthotticalana subsp. idukkiensis (Ravi \& Anil Kumar) Kiran Raj } \\
\text { \& Sivad., comb. \& stat. nov. (Dimeria idukkiensis Ravi \& Anil Kumar, } \\
\text { Rheedea 2(2): 104. 1992) } \\
\text { D. kurzii Hook. f. } \\
\text { D. lawsonii (Hook. f.) C.E.C. Fisch. } \\
\text { D. mahendragiriensis Ravi, H.O. Saxena \& Brahmam } \\
\text { D. mooneyi Raizada } \\
\text { D. mooneyi subsp. borii (Sreek. et al.) Kiran Raj \& Sivad., comb. \& stat. } \\
\text { nov. (Dimeria borii Sreek., V.J. Nair \& N.C. Nair, J. Econ. Taxon. Bot. } \\
\text { 3(2): 657.1982) } \\
\text { D. namboodiriana Ravi \& N. Mohanan } \\
\text { D. pubescens Hack. } \\
\text { D. raizadae V.J. Nair, Sreek. \& N.C. Nair (=Dimeria eradii Ravi, syn. } \\
\text { nov.) } \\
\text { D. raviana Kiran Raj \& Sivad. } \\
\text { D. thwaitesii Hack. }\end{array}$ \\
\hline
\end{tabular}


Bor (1953) pointed out the necessity of a further detailed study of more specimens of all species for a better understanding of diversity and extent of intraspecific variation. After 1953, a fairly large number of new species have been described, and it was found after field work and morphological examinations in the herbarium that some could not be properly assigned to a section. Also, the Capillares and Loriformes contained species with strictly triquetrous racemerachises, overlapping spikelets, and pedicels closely appressed to the rachis. Dimeria acinaciformis is characterized by the presence of triquetrous raceme-rachises and compressed pedicels.

Considering all the above aspects, a revised infrageneric classification of Dimeria is proposed here.

The raceme structure of the representative taxa of the sections is illustrated in Fig. 2 as an aid for easy understanding of the diagnostic characters.

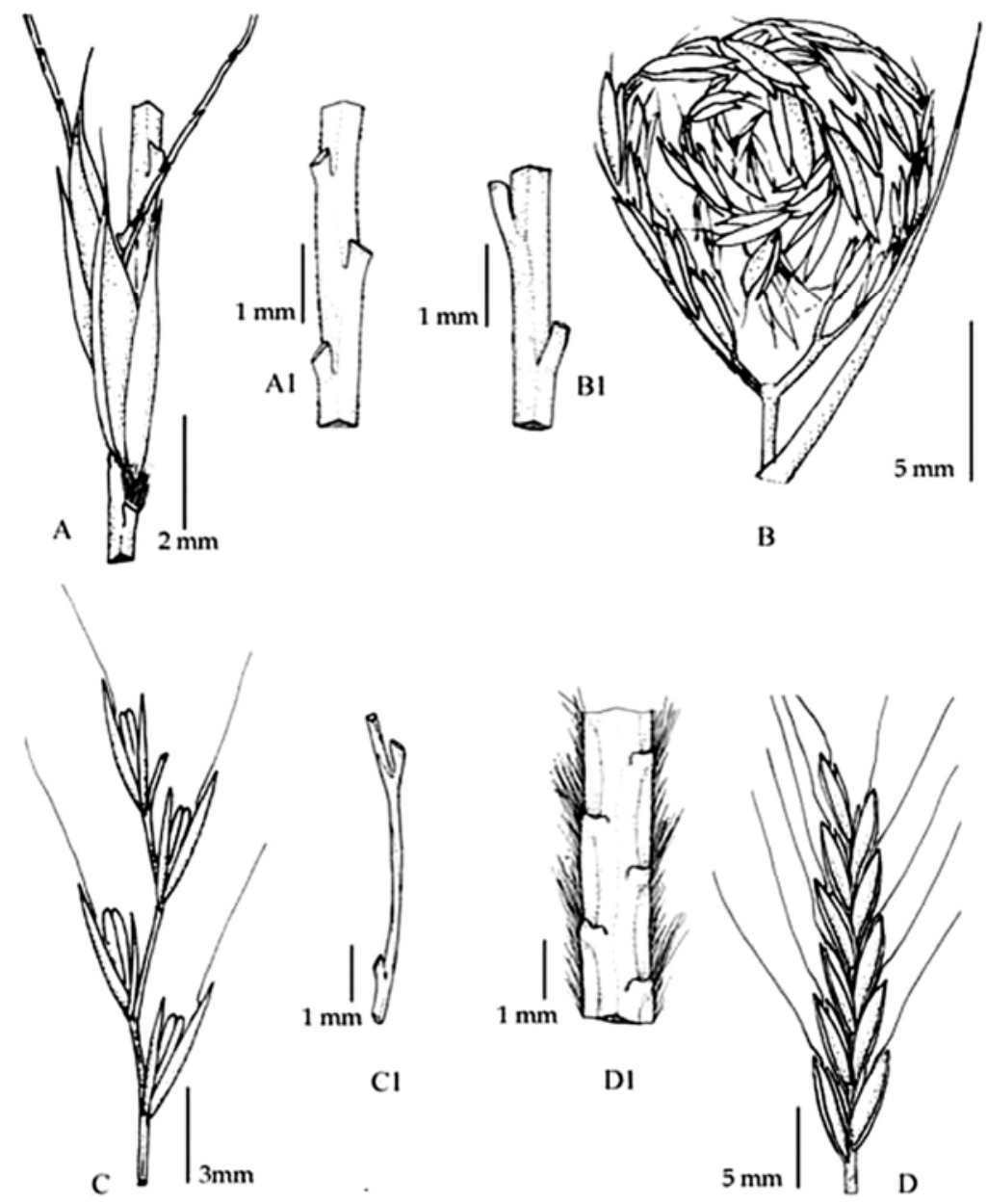

Fig. 2. Portions of racemes and rachises of representative taxa of the sections of Dimeria. A \& A1. Dimeria avenacea (sect. Dimeria); B \& B1. D. woodrowii (sect. Annulares); C \& C1. D. hohenackeri (sect. Capillares); D \& D1. D. balakrishnaniana (sect. Loriformes). (Drawings by M.S. Kiran Raj) 


\section{Dimeria R. Br. sect. Dimeria}

Type: Dimeria acinaciformis R. Br.

Annuals or perennials. Racemes 2 or 3, rarely 1; rachis of raceme triquetrous, trigonous in cross section, occasionally zigzag, usually wingless, if winged, only at the internodes; spikelets closely packed on the rachis, usually overlapping; raceme internodes c. $0.5 \mathrm{~mm}$ long; glumes slightly diverging at anthesis; pedicels $0.3-0.5 \mathrm{~mm}$ long, trigonous to flat, closely appressed to the rachis.

Distribution: Widely distributed in Tropical Asia to North Australia.

Notes: There are 12 species in Peninsular India of which seven, viz. D. acutipes Bor, D. avenacea (Retz.) C.E.C. Fisch., D. connivens Hack., D. lehmannii (Nees \& Steud.) Hack., D. ornithopoda Trin., D. orissae Bor and D. trimenii Hook. f. were included by Bor (1953) in sect. Loriformes. Dimeria chelariensis Ravi (1995) is a synonym of D. copeana Sreek. et al. (Table 1).

According to Art. 22.1. of the ICN (McNeill et al., 2012), an autonym is required and the correct name is Dimeria sect. Dimeria.

\section{Dimeria R. Br. sect. Annulares Bor}

Type: Dimeria woodrowii Stapf

Annuals. Racemes 2 or 3, peduncle bent downwards or erect at maturity; rachis of raceme compressed, trigonous on one side and convex on the other, straight when young and curved at maturity to form a 'globule', or a single or double 'ringlet' carrying the spikelets along the inner side; raceme internodes up to $1 \mathrm{~mm}$ long; spikelets distantly arranged along the rachis; upper glume distinctly winged, or minutely winged, or wingless; pedicels terete, not compressed.

Distribution: Two species in Peninsular India (Table 1), and so far known only from lateritic plains of the Northern Western Ghats.

\section{Dimeria R. Br. sect. Capillares Bor}

Lectotype: Dimeria hohenackeri Hochst. ex Miq. (here designated)

Annuals or perennials. Racemes 3 to 5, rarely up to 11; rachis of raceme capillary and very thin, nearly triangular or circular in cross section, not winged; spikelets very distantly arranged along the rachis, late disarticulation from the pedicels; raceme internodes $2.5-3.5 \mathrm{~mm}$ long; glumes widely diverging at anthesis; pedicels $0.5-1.5 \mathrm{~mm}$ long, terete, not compressed.

Distribution: Restricted to Indian subcontinent (Western Ghats region of Peninsular India, Sri Lanka and Myanmar); three species in Peninsular India (Table 1).

Notes: Bor (1953) included seven species in Dimeria. sect. Capillares, and the type was not designated and hence the present lectotypification. In the present classification, three species are transferred to sect. Dimeria (Table 1).

\section{Dimeria R. Br. sect. Loriformes Bor}

Lectotype: Dimeria pubescens Hack. (here designated)

Mostly annuals. Racemes 1 or 2, rarely 3; rachis of raceme compressed; dorsally flattened in cross section, winged; spikelets compactly arranged along the rachis, early disarticulation from the pedicels; raceme internodes $0.5-1.0 \mathrm{~mm}$ long; pedicels $0.3-0.5 \mathrm{~mm}$ long, distinctly compressed, flat, appressed to the wing and axis of rachis.

Distribution: Peninsular India, Myanmar and Sri Lanka; mostly occurring in Peninsular India with 17 species. 
Notes: Bor (1953) did not designate a type for the section and hence it is lectotypified here. Seven species are excluded from Bor's Loriformes, and here placed in Dimeria sect. Dimeria.

Three Peninsular Indian species, viz. Dimeria sivarajanii N. Mohanan and Ravi (1996), D. idukkiensis Ravi and Anil Kumar (1992) and D. borii Sreek. et al. (1982) are reduced to subspecies of D. bialata C.E.C. Fisch. (1933), D. kurumthotticalana Jacob (1947) and D. mooneyi Raizada (1950), respectively (Table 1); two species, viz. D. copei Ravi (1996) and D. eradii Ravi (1995) are reduced to D. kalavoorensis Ravi (1996) and D. raizadae V.J. Nair et al. (1983), respectively; two species, viz. D. kollimalayana M. Mohanan and A.V.N. Rao (1984) and D. jayachandranii Arisdason and P. Daniel (2009), are regarded as conspecific with D. deccanensis Bor (1953), and they are treated as new synonyms (Table 1).

\section{Key to the Sections of Dimeria in Peninsular India}

1. Racemes divergent; rachis of raceme always straight, never coiled; spikelets arranged along the outside and exposed.

- Racemes non-divergent; rachis of raceme coiled to form a 'globule' or 'ringlet'; spikelets arranged along the inner side of rachis.

Dimeria sect. Annulares

2. Rachis of raceme capillary and filiform, thin, wingless, angled to terete in cross section; spikelets distantly arranged on rachis, not readily disarticulating with pedicels; pedicles $1.0-1.5 \mathrm{~mm}$ long, terete, glabrous.

- Rachis of raceme not capillary, stout, winged or not, trigonous or compressed in cross section; spikelets compactly arranged on rachis, easily disarticulating with pedicels; pedicels $0.5-1.0 \mathrm{~mm}$ long, flat, often ciliate at the outer margin.

3. Spikelet usually overlapping; rachis of raceme triquetrous, $0.5-0.7 \mathrm{~mm}$ wide, often minutely winged at the internode, scaberulous to sparsely ciliate along margin; pedicels compressed but not flat, completely appressed to the raceme-rachis.

Dimeria sect. Capillares

Spikelets never overlapping; rachis of raceme abaxially flat, $0.8-1.5 \mathrm{~mm}$ wide, distinctly winged, glabrous to ciliate along margin; pedicels flat, basal half appressed to raceme-rachis and upper half attached to wing of rachis.

Dimeria sect. Loriformes

\section{Acknowledgements}

The first author is indebted to the Council of Scientific and Industrial Research (CSIR), New Delhi for the award of Senior Research Fellowship in 2001, the International Association for Plant Taxonomy (IAPT), Vienna for the Plant Systematics Research Grant Award in 2007 while working earlier at the University of Calicut, Kerala, India, and the University Grants Commission (UGC), New Delhi for granting a Minor Research Project in 2013. Sincere gratitude is expressed towards Prof. N. Ravi, an eminent agrostologist of Kerala and former Head of the Department of Botany, Sree Narayana College, Kollam, India for constant encouragements and comment on the manuscript. The authors are grateful towards the curators of AHMA, BM, BLAT, BSI, CAL, MH and $\mathrm{K}$ for permitting to study the specimens available at their respective herbaria, and providing necessary literature and cibachrome photographs of specimens. The second and fourth authors thankfully extend their appreciation to the Deanship of Scientific Research at the King Saud 
University for encouragements and support extended through the research group project No. RGPVPP-135.

\section{References}

Arisdason, W. and Daniel, P. 2009. Dimeria jayachandranii (Poaceae), a new species from the Western Ghats, India. Kew Bull. 64: 345-347.

Bentham, G. 1881. Notes on Gramineae. J. Linn. Soc., Bot. 19: 67.

Bentham, G. 1883. Gramineae. In: Bentham, G. and Hooker, J.D., Genera Plantarum 3: 1128. Reeve \& Co., Williams \& Norgate, London.

Bor, N.L. 1953. Notes on Asiatic grasses XI. The genus Dimeria R. Br. in India and Burma. Kew. Bull. 1952(7): 553-592.

Brown, R. 1810. Prodromus florae Novae Hollandiae et insulae Van Diemen, 1. J. Johnson, London, 204 pp.

Camus, E.G.and Camus, A. 1922.Graminées. In: Lecomte, H. and Humbert, H. (Eds), Flore Générale de L'Indo-Chine, 7. Masson, Paris, pp. 202-650.

Chen, S.L. and Phillips, S.M. 2006. Dimeria. In: Zhengyi, W., Raven, P.H. and Hong, D.Y. (Eds), Flora of China, 22. Science Press, Beijing and Peoples Republic of China and Missouri Botanical Garden Press, St. Louis, Missouri, pp. 614-616.

Clayton, W.D. 1972. Gramineae. In: Hutchinson, J. and Dalziel, J.M. (Eds), Flora of West Tropical Africa, 3, $2^{\text {nd }}$ edition, Crown Agents, London, pp. 413-414.

Clayton, W.D. and Renvoize, S.A. 1986. Genera Graminum. Grasses of the World. Kew Bull. Add. Ser. XIII. pp. 1-389.

Clayton, W.D., Vorontsova, M.S., Harman, K.T. and Williamson, H. 2006 (onwards). GrassBase - The Online World Grass Flora. <http://www.kew.org/data/grasses-db.html>. Retrieved on 2 March 2015.

Endlicher, S.L. 1836. Andropogoneae. In: Genera plantarum secundum ordines naturales disposita. F. Beck, Wien, pp. 106.

Estep, M.C., McKain, M.R., Diaz, D.V., Zhong, J., Hodge, J.G., Hodkinson, T.R., Layton, D.J., Malcomber, S.T., Pasqueth, R. and Kellogg, E.A. 2014. Allopolyploidy, diversification, and the Miocene grassland expansion. Proc. Natl. Acad. Sci. USA 111(42): 15149-15154.

Fischer, C.E.C. 1933. Dimeria bialata. XLI - New or little-known plants from South India. Bull. Misc. Inform. Kew 1933(7): 339-357.

Gilliland, H.B. 1971. A revised flora of Malaya. An illustrated systematic account of the Malayan flora, including commonly cultivated plants 3. Government Printing Office, Singapore, pp. 1-319.

Hackel, E. 1889. Dimerieae. In: A. and C. de Candolle, Monographiae phanerogamarum 6. G. Masson, Paris, pp. 76-90.

Henty, E.E. 1969. A manual of the grasses of New Guinea. Bot. Bull. 1. Lae, New Guinea, pp. 1-215.

Hooker, J.D. 1896. Dimeria. In: Hooker, J.D. (Ed.), Flora of British India, 7. Reeve \& Co. Ltd., London, pp. $103-106$.

Jacob, K.C. 1947. Some new species of South Indian Plants. J. Bombay Nat. Hist. Soc. 47(1): 47-51.

Jansen, P. 1953. Notes on Malaysia grasses - I. Reinwardtia 2: 265-267.

Kellogg, E.A. and Watson, L. 1993. Phylogenetic studies on a large data set. I. Bambusoideae, Andropogonodae and Pooideae (Gramineae). Bot. Rev. 59: 273-343.

Kiran Raj, M.S. 2008. Taxonomic revision of the subtribe Dimeriinae Hack. of Andropogoneae (Poaceae Panicoideae) in Peninsular India. Ph.D. thesis (Unpublished). University of Calicut, India, pp. 1-409.

Kiran Raj, M.S. and Sivadasan, M. 2008. A new species of Dimeria R. Br. (Poaceae) from Goa, India. Novon 18: $183-186$.

Kiran Raj, M.S., Sivadasan, M., Alfarhan, A.H. and Veldkamp, J.F. 2015. Dimeria raviana (Poaceae: Panicoideae), a new species from South Western Ghats, India. Phytotaxa 195: 193-196.

Kiran Raj, M.S., Sivadasan, M., Veldkamp, J.F., Alfarhan, A.H. and Thomas, J. 2013a. Nanooravia gen. nov., subtribe Dimeriinae (Poaceae-Panicoideae-Andropogoneae) from India. Nordic J. Bot. 31: $161-165$.

Kiran Raj, M.S., Sivadasan, M., Veldkamp, J.F., Alfarhan, A.H. and Thomas, J. 2013b. Validation of Nanooravia santapaui (Poaceae-Panicoideae-Andropogoneae-Dimeriinae). Nordic J. Bot. 31: 638. 
Lazarides, M. 1980. Phanerogamarum monographiae XII: the tropical grasses of Southeast Asia. pp. 1-225.

McNeill, J., Barrie, F.R., Buck, W.R., Demoulin, V., Greuter, W., Hawksworth, D.L., Herendeen, P.S., Knapp, S., Marhold, K., Prado, J., Prud'homme van Reine, W.F., Smith, G.F., Wiersema, J.H. and Turland, N.J. 2012. International Code of Nomenclature for algae, fungi and plants (Melbourne Code) adopted by the Eighteenth International Botanical Congress Melbourne, Australia, July 2011. Regnum Vegetabile 154: 1-240.

Miquel, F.A.W. 1851. Analecta botanica indica. 2. Gramineae quaedam, praesertim Canaranae. Verhandelingen der EersteKlasse van het Koninklijk Nederlandsch Instituut van Wetenschappen III, 4: 30-38, reprinted as Analecta Botanica Indica 2 (1851): 34-35.

Mohanan, M. and Rao, A.V.N. 1984 (1983, published in 1984). A new species of Dimeria R. Br. (Poaceae) from Kollimalai, South India. J. Bombay Nat. Hist. Soc. 80(3): 615-617.

Mohanan, N. and Ravi, N. 1996. Dimeria sivarajanii (Poacaeae), a new species From Kerala, India. Rheedea 6(2): 47-50.

Nair, V.J., Sreekumar, P.V. and Nair, N.C. 1983. Dimeria raizadae - a new species of Poaceae from Kerala, India. Indian J. For. 6(2): 163-165.

Raizada, M.B. 1950. Dimeria mooneyi. In: Mooney, H., Supplement to the botany of Bihar and Orissa. Catholic Press, Ranchi, p. 263.

Ravi, N. 1995. Two new species of Dimeria R. Br. (Poaceae) from Kerala, India. Rheedea 5(1): 37-42.

Ravi, N. 1996. Another two new species of Dimeria R. Br. (Poaceae) from Kerala, India. Blumea 41(1): 251-256.

Ravi, N. and Anil Kumar, N. 1992. New and interesting species of Dimeria R. Br. (Poaceae) from Kerala, India. Rheedea 2(2): 101-107.

Ridley, H.N. 1925. The Flora of the Malay Peninsula, 5. Reeve \& Co. Ltd., London, pp. 1-470.

Roberty, G. 1960. Monographie systématique des Andropogonées du globe. Boissiera 9: 396-402.

Schmid, M. 1958. Flore agrostologique de l'Indochine. L'Agronomie Tropicale. Office de la Recherche Scientifique et Technique Outre-mer (ORSTOM), Paris, pp. 1-703.

Sreekumar, P.V., Nair, V.J. and Nair, N.C. 1982. Dimeria borii (Poaceae): a new species from Kerala, India. J. Econ. Taxon. Bot. 3(2): 657-658.

Steudel, E.G. 1854. Synopsis plantarum glumacearum, 1. J.B. Metzler, Stuttgart, pp. 1-474.

Teerawatananon, A., Boontia, V., Chantarasuwan, B., Hodkinson, T.R. and Sungkaew, S. 2014. A taxonomic revision of the genus Dimeria (Poaceae: Panicoideae) in Thailand. Phytotaxa 186: 137-147.

Veldkamp, J.F. 2015. Arundinella (Gramineae) in Malesia with notes on other taxa and on aluminium accumulation. Blumea 59: 167-179.

(Manuscript received on 20 April 2015; revised on 2 June 2015) 